\title{
ABNORMAL RETINAL CORRESPONDENCE* A PRELIMINARY REPORT ON THE TREATMENT OF ABNORMAL RETINAL CORRESPONDENCE BY CÜPPERS'S AFTER-IMAGE METHOD
}

BY

\author{
S. MAYWEG AND H. H. MASSIE \\ Orthoptic Department, High Holborn Branch of Moorfields Eye Hospital (Director: T. Keith Lyle)
}

\begin{abstract}
ABNORMAL retinal correspondence is found to be present in a considerable number of cases of concomitant strabismus. Müller (1826) thought that the anomalous projection was due to a congenital malposition of the macula of the squinting eye. It was suggested by von Graefe (1855) that the anomalous projection occurred as a result of the squint. Parinaud (1899) postulated that normal binocular function was possible in abnormal retinal correspondence, the macula of the unaffected eye being used in conjunction with a point of eccentric fixation in the squinting eye. Bielschowsky (1937) and other workers have denied that binocular vision of any useful degree could develop when one eye was fixing eccentrically. Chavasse (1939), Duke-Elder (1949), and Lyle and Walker (1950) state that abnormal retinal correspondence is prompted by a desire to develop binocular vision. Burian $(1947,1951)$ maintains that anomalous correspondence was acquired through usage and was an adaptation of the sensory apparatus of the eyes to their abnormal position.

Various methods of treating abnormal retinal correspondence have been developed as the treatment of strabismus has improved. Travers $(1940,1950)$ recommended operation as being the most important single factor in the development of normal retinal correspondence, combined with orthoptic exercises. Others, including Lyle and Jackson (1940), have used kinetic stimulation at the objective angle, but with only a moderate degree of success; because of this, the method is rarely used in England now. Recently, however, Cüppers (1956) has developed a new method of treatment based on the Bielschowsky after-image test. A series of 22 cases have been treated by this method at the High Holborn Branch of Moorfields Eye Hospital.
\end{abstract}

\section{Clinical Material}

The patients selected for treatment by Cüppers' method were mostly those who had previously had some form of amblyopia, often associated with an eccentric fixation. Their ages varied between 5 and 12 years and the age at onset of strabismus varied from birth to 2 years. Nearly all these children had been treated previously in the Orthoptic Department and had been discharged as cosmetically satisfactory.

* Received for publication May 3, 1958. 


\section{Method of Treatment}

The principles of treatment were those used to restore the normal sensory relationship of the two retinae.

After insuring that the fixation was central in each eye, and that the visual acuity had been improved in the amblyopic eye to such a degree as to help the possible development of binocular vision, treatment was given as follows:

(1) Occlusion.-In unilateral strabismus, occlusion was maintained on the fixing eye until the squint had become alternating. It was then changed each day from one eye to the other in order to maintain the visual acuity in each eye, and to discourage the anomalous sensory relationship. The same procedure was adopted if the squint was already alternating.

(2) Orthoptic Exercises.-These were given using the after-image technique as a control. The giving of the after-image depended on alternative foveal stimulation, thus overcoming the facultative suppression which is normally present. Each fovea was subjected in turn to a stimulus which varied slightly for each eye. With the tube of the major synoptophore adjusted to the objective angle of strabismus, the stimulus, in a linear form, produced by a specially-constructed slide, was first inserted into the right hand tube so that the beam of light was vertical. A bright light was turned on behind this slide for approximately 20 seconds and the patient was instructed to observe a red fixation point in the centre of the bar of light so produced. The illumination was then turned on behind a horizontally placed slide in front of the left eye for a further 20 seconds, after which the slides were removed and flashing illumination was commenced in order to stimulate the formation of the after-image. The flashing could be adjusted so as to vary the dark and light periods independently, and it was possible to stimulate the eyes simultaneously or alternately. While flashing was in progress the patient was asked to describe the negative after-image seen projected into space and to indicate the image form by holding two pencils in the appropriate position. If abnormal retinal correspondence was present the lines would be seen uncrossed $-\frac{1}{1}$, or partly crossed $-\frac{1}{1}$, and if normal retinal correspondence was present the lines would be seen as a symmetrical cross -

It was usual, at the beginning of the course of treatment, to find the afterimages uncrossed. However, with daily treatment on the major synoptophore, encouraging the patient to bring the lines together, it was found that, in many cases, the two lines would gradually come to form a cross. This appeared only fleetingly at first, but later the cross occurred more permanently. With further treatment, the after-images would form a cross without the aid of flashing illumination. When the after-images showed, by the formation of a symmetrical cross, that normal retinal correspondence had developed, one 
of a pair of simultaneous perception slides was inserted; when the picture was centred on the cross, the second slide of the pair was inserted. The two slides were only allowed to remain if the pictures were correctly superimposed, and provided that the cross was still visible.

If the after-images showed no sign of forming a cross after approximately twenty sessions, this method of treatment was discontinued.

During the earlier stages of treatment, the subjective angle, or the angle at which the abnormal correspondence had developed, was always avoided until the correspondence had apparently become normal. When normal retinal correspondence had been achieved, the patient was allowed to find his own subjective angle, still using the cross as a means of control.

(3) Surgery.-An operation to restore the eyes to a normal position was not contemplated until the after-image test showed that normal correspondence was fairly constant and that some range of fusion was possible on the synoptophore. It was found desirable to aim at securing orthophoria, or even a few degrees of divergence in the case of a convergent squint, and a few degrees of convergence in the case of a divergent squint.

(4) Post-Operative Treatment.-Total occlusion was maintained postoperatively until fusion was possible on the synoptophore without the aid of flashing illumination. Then a trial period of a few days without occlusion was allowed and, provided that there was no reversion to the anomalous projection, occlusion was discontinued. Treatment was carried out with the synoptophore, using fusion slides of decreasing sizes. Cheiroscope drawing and bar-reading were employed as the range of fusion increased. A close check was maintained by using Worth's lights and red and green glasses, to ensure that suppression was not occurring.

The patients were given pre-operative and post-operative treatment at least three times a week, but daily where possible.

\section{Results}

The results shown in the Table are those which were obtained at a followup examination carried out 3 to 5 months after the original treatment had been completed.

Of 22 patients with abnormal retinal correspondence treated, four (Cases $5,18,20,22)$ developed normal retinal correspondence. They had had a persistently abnormal retinal correspondence before treatment and two of them developed a small range of fusion. One patient (Case 6) gave a variable response before treatment, sometimes normal, and sometimes abnormal, and a constant normal retinal correspondence after treatment. A further patient (Case 11), who showed abnormal retinal correspondence before treatment, gave a normal response for near, but an abnormal response for distance, after treatment. 


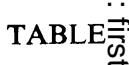

RESULTS OF TREATING 22 PATIENTS WITH ABNORMALC

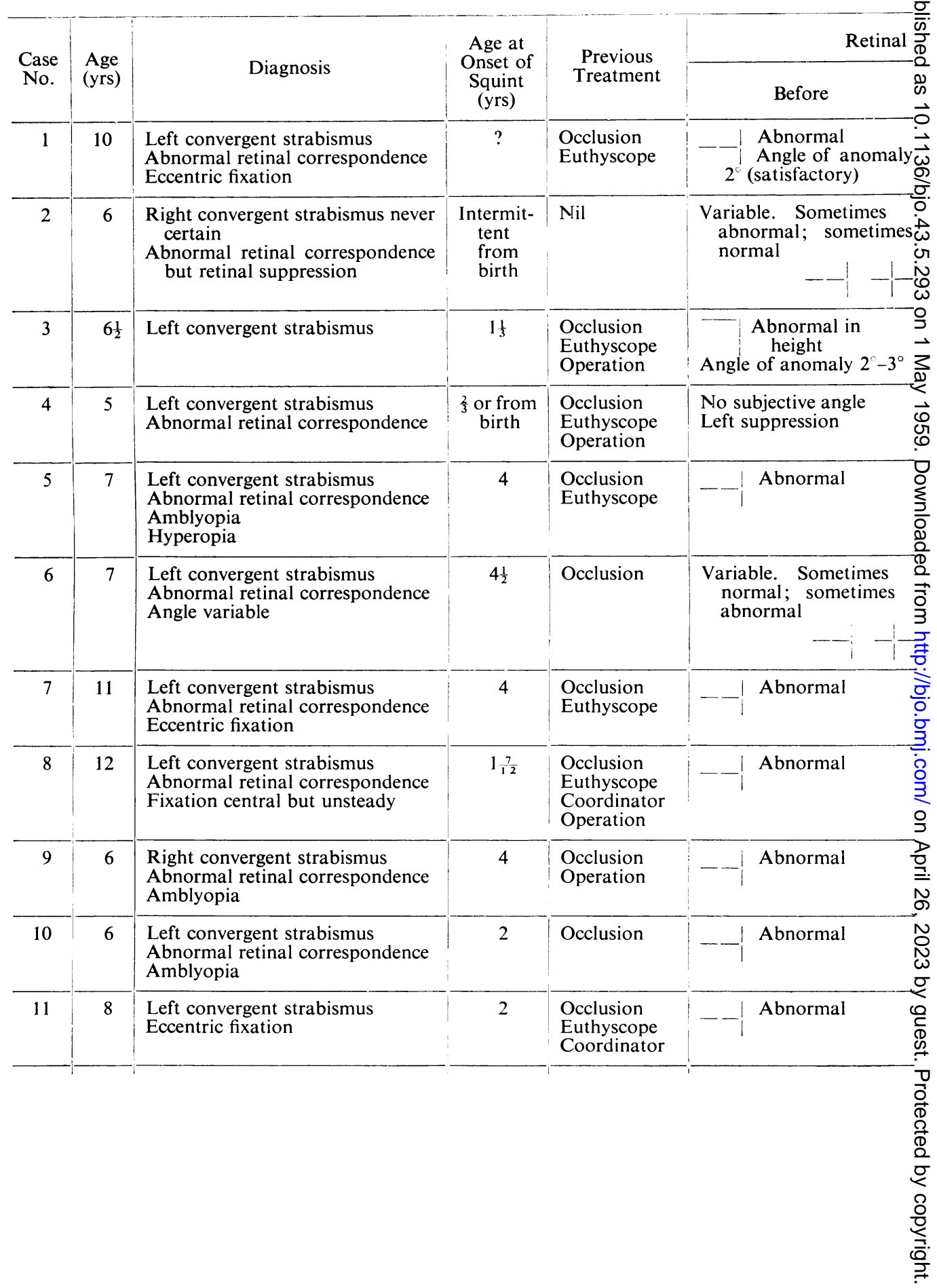


RETINAL CORRESPONDENCE BY CÜPPERS'S AFTER-IMAGE METHOD

\begin{tabular}{|c|c|c|c|c|}
\hline \multirow{2}{*}{$\frac{\text { Correspondence }}{\text { After }}$} & \multicolumn{2}{|c|}{ Binocular Vision on Synoptophore } & \multirow{2}{*}{$\begin{array}{l}\text { Stereoscopic } \\
\text { Vision }\end{array}$} & \multirow{2}{*}{$\begin{array}{l}\text { No. of } \\
\text { Treat- } \\
\text { ments }\end{array}$} \\
\hline & $\begin{array}{c}\text { Simultaneous } \\
\text { Macular Perception }\end{array}$ & Fusion & & \\
\hline$\ldots-\mid$ Abnormal & None & $\begin{array}{l}\text { None } \\
\text { Can alternate }\end{array}$ & None & 15 \\
\hline-1 Variable & $\begin{array}{l}\text { Yes } \\
\text { at }+19^{\circ} R / L^{4} \triangle\end{array}$ & Right suppression & None & 13 \\
\hline$-7 \begin{array}{l}\text { Abnormal } \\
\text { in height }\end{array}$ & None & $\begin{array}{l}\text { None } \\
\text { Can alternate }\end{array}$ & None & 7 \\
\hline-1 Abnormal & $\begin{array}{l}\text { Angle of } \\
\text { anomaly } 2^{\circ}-3^{\circ}\end{array}$ & $\begin{array}{l}\text { Abnormal fusion } \\
\text { Left divergent strabismus }\end{array}$ & None & 13 \\
\hline - _ Normal & $\begin{array}{l}\text { Yes } \\
\text { Variable }\end{array}$ & $\begin{array}{l}\text { Weak } \\
\text { Left convergent strabis- } \\
\text { mus near and distance }\end{array}$ & None & 16 \\
\hline - Normal & $\begin{array}{l}\text { Yes } \\
\text { at } 1^{\circ} \mathbf{L} / \mathbf{R} 2 \Delta \\
\text { (Intermittent) }\end{array}$ & $\begin{array}{l}\text { Weak } \\
\text { Range } 8^{\circ} \\
\text { Left convergent strabismus }\end{array}$ & Partial & 18 \\
\hline __ Abnormal & None & None & None & 16 \\
\hline-1 Abnormal & None & None & None & 22 \\
\hline __ Abnormal & None & None & None & 21 \\
\hline __ Abnormal & None & None & None & 14 \\
\hline $\begin{array}{l}\text { Normal for near } \\
\text { Abnormal for } \\
\text { distance }\end{array}$ & $\begin{array}{l}\text { Yes } \\
\text { Cover Test: Binocu } \\
\text { manifest converger }\end{array}$ & $\begin{array}{l}\text { Poor Range } \\
\text { or fixation for near, slight } \\
\text { e for distance }\end{array}$ & Weak & 50 \\
\hline
\end{tabular}


(continued)

\begin{tabular}{|c|c|c|c|c|c|}
\hline \multirow{2}{*}{$\begin{array}{l}\text { Case } \\
\text { No. }\end{array}$} & \multirow{2}{*}{$\begin{array}{l}\text { Age } \\
\text { (yrs) }\end{array}$} & \multirow{2}{*}{ Diagnosis } & \multirow{2}{*}{$\begin{array}{l}\text { Age at } \\
\text { Onset of } \\
\text { Squint } \\
\text { (yrs) }\end{array}$} & \multirow{2}{*}{$\begin{array}{l}\text { Previous } \\
\text { Treatment }\end{array}$} & \multirow[t]{2}{*}{ Retinal } \\
\hline & & & & & \\
\hline 12 & 8 & $\begin{array}{l}\text { Left convergent strabismus } \\
\text { Abnormal retinal correspondence } \\
\text { Eccentric fixation }\end{array}$ & 4 & $\begin{array}{l}\text { Occlusion } \\
\text { Euthyscope } \\
\text { Coordinator }\end{array}$ & $-\ldots$ Abnormal \\
\hline 13 & 8 & $\begin{array}{l}\text { Left convergent strabismus } \\
\text { Abnormal retinal correspondence }\end{array}$ & 2 & Occlusion & $-\ldots$ Abnormal \\
\hline 14 & 8 & $\begin{array}{l}\text { Left convergent strabismus } \\
\text { Abnormal retinal correspondence } \\
\text { Amblyopia }\end{array}$ & $?$ & Occlusion & - $\mid$ Abnormal \\
\hline 15 & 8 & $\begin{array}{l}\text { Right convergent strabismus } \\
\text { Abnormal retinal correspondence } \\
\text { Eccentric fixation }\end{array}$ & 1 & $\begin{array}{l}\text { Occlusion } \\
\text { Euthyscope } \\
\text { Operation }\end{array}$ & $-\ldots \mid$ Abnormal \\
\hline 16 & 6 & $\begin{array}{l}\text { Left convergent strabismus } \\
\text { Abnormal retinal correspondence } \\
\text { Left hypertropia }\end{array}$ & 6 months & $\begin{array}{l}\text { Occlusion } \\
\text { Operation }\end{array}$ & $-\underset{\substack{\text { Abnormal, but } \\
\text { sometimes nor } \\
\text { mal }}}{\text { - }}$ \\
\hline 17 & 6 & $\begin{array}{l}\text { Left convergent strabismus } \\
\text { Abnormal retinal correspondence } \\
\text { Central fixation }\end{array}$ & $?$ & $\begin{array}{l}\text { Occlusion } \\
\text { Euthyscope } \\
\text { Coordinator }\end{array}$ & $\begin{array}{l}\text { Variable. Sometimes } \\
\text { abnormal; sometimes } \\
\text { normal }\end{array}$ \\
\hline 18 & 10 & $\begin{array}{l}\text { Right convergent strabismus } \\
\text { Abnormal retinal correspondence } \\
\text { Eccentric fixation }\end{array}$ & 3 & $\begin{array}{l}\text { Occlusion } \\
\text { Euthyscope } \\
\text { Coordinator } \\
\text { Operation }\end{array}$ & - - $\begin{array}{l}\text { Abnormal } \\
\text { Right suppressior }\end{array}$ \\
\hline 19 & 12 & $\begin{array}{l}\text { Left divergent strabismus } \\
\text { (consecutive) } \\
\text { Abnormal retinal correspondence } \\
\text { Fixation central but unsteady, } \\
\text { flicking on and off macula }\end{array}$ & $1 \frac{1}{4}$ & $\begin{array}{l}\text { Occlusion } \\
\text { Euthyscope } \\
\text { Coordinator }\end{array}$ & $\begin{array}{l}\text { Normal after treatmen } \\
\text { for right amblyopia }\end{array}$ \\
\hline 20 & 10 & $\begin{array}{l}\text { Left convergent strabismus } \\
\text { Abnormal retinal correspondence } \\
\text { Fixation central but unsteady }\end{array}$ & 4 & $\begin{array}{l}\text { Occlusion } \\
\text { Euthyscope } \\
\text { Coordinator } \\
\text { Operation }\end{array}$ & - Abnormal \\
\hline 21 & $6 \frac{1}{2}$ & $\begin{array}{l}\text { Left convergent strabismus } \\
\text { Abnormal retinal correspondence } \\
\text { Fixation central but unsteady }\end{array}$ & 6 months & $\begin{array}{l}\text { Occlusion } \\
\text { Euthyscope } \\
\text { Coordinator } \\
\text { Operation }\end{array}$ & - $\mid$ Abnormal \\
\hline 22 & 6 & $\begin{array}{l}\text { Left convergent strabismus } \\
\text { Abnormal retinal correspondence }\end{array}$ & 5 & $\begin{array}{l}\text { Occlusion } \\
\text { Operation }\end{array}$ & $--\mid$ Abnormal \\
\hline
\end{tabular}




\begin{tabular}{|c|c|c|c|c|}
\hline \multirow{2}{*}{$\frac{\text { Correspondence }}{\text { After }}$} & \multicolumn{2}{|c|}{ Binocular Vision on Synoptophore } & \multirow{2}{*}{$\begin{array}{l}\text { Stereoscopic } \\
\text { Vision }\end{array}$} & \multirow{2}{*}{$\begin{array}{l}\text { No. of } \\
\text { Treat- } \\
\text { ments }\end{array}$} \\
\hline & $\begin{array}{c}\text { Simultaneous } \\
\text { Macular Perception }\end{array}$ & Fusion & & \\
\hline _- Abnormal & None & None & None & 8 \\
\hline _- Abnormal & None & None & None & 9 \\
\hline _- Abnormal & None & None & None & 23 \\
\hline$-\ldots$ Abnormal & None & $\begin{array}{l}\text { None } \\
\text { (Non-cooperative) }\end{array}$ & None & 21 \\
\hline $\begin{array}{l}\text { Sometimes normal; } \\
\text { sometimes abnormal }\end{array}$ & $\begin{array}{l}\text { Unsteady } \\
\text { at } 5^{\circ}, \mathrm{L} / \mathbf{R} 9 \Delta\end{array}$ & $\begin{array}{l}\text { Doubtful range of } 4^{\circ} \\
\text { Cover Test: Right con- } \\
\text { vergent strabismus for } \\
\text { near, right divergent } \\
\text { strabismus for distance }\end{array}$ & $\begin{array}{c}\text { None } \\
\text {. }\end{array}$ & 20 \\
\hline - _ Normal & Yes at $0^{\circ}$ & $\begin{array}{l}\text { Yes, add. }+6^{\circ} \text { abd. }-4^{\circ} \\
\text { Cover Test: No deviation }\end{array}$ & Yes & 13 \\
\hline - I Normal & Yes & $\begin{array}{l}\text { Poor range } \\
\text { Right amblyopia persists }\end{array}$ & None & 19 \\
\hline $\begin{array}{l}\text { Visual acuity improved } \\
\text { to } 6 / 36 \\
\text { Fixation still unsteady }\end{array}$ & Yes & $\begin{array}{l}\text { Good range immediately } \\
\text { after treatment, but } \\
\text { none demonstrated at } \\
\text { latest examination }\end{array}$ & No & 40 \\
\hline -I_ Normal & Yes at $0^{\circ}$ & $\begin{array}{l}\text { Weak range }+12^{\circ} \text { to } 0^{\circ} \\
\text { Cover Test: Exophoria } \\
\text { for near, straight for } \\
\text { distance }\end{array}$ & No & 24 \\
\hline$\ldots$ Abnormal & None & None & None & 12 \\
\hline - - Normal & Yes & Weak range & None & 13 \\
\hline
\end{tabular}




\section{Discussion}

The number of treatments ranged between seven and fifty (average between fifteen and twenty). The patients with a large angle of anomaly usually responded more quickly than those with a very small angle. Also, those who had developed a degree of low grade binocular vision, using an eccentric point on the squinting eye, showed a less rapid response. Patients who had originally shown a high degree of amblyopia responded better than those with no amblyopia. The children who had had occlusion for several months during treatment for eccentric fixation responded better than those who started treatment without previous occlusion. It was also found that the younger children responded more quickly than the older ones. The patients who showed no improvement were mainly those who showed lack of cooperation in maintaining occlusion, or who had a very fixed abnormal retinal correspondence with a range of fusion on the synoptophore at the subjective angle. It was felt, however, that the latter group might have responded had it been possible to prolong the course of treatment. The fact that one eye was constantly occluded may have been responsible for the slow improvement in the range of fusion, particularly as the everyday stimulus for binocular function was lacking.

Patients suitable for this treatment must be chosen carefully. It is essential for them to be intelligent and fully cooperative. It is desirable that children under the age of 7 , who have been cured of eccentric fixation, and whose eyes are straight or have been made straight by operation, should be treated by this method to prevent any deterioration in visual acuity. Patients over the age of 7, who have a small angle of anomaly, should not be given more than twenty sessions of treatment; if there is then no improvement, they should be taught to alternate with the aid of red and green glasses. In such cases the development of binocular vision seems doubtful and diplopia may result.

Although the number of patients treated is too small to draw any definite conclusions from the results obtained, it would appear that, in certain cases of convergent strabismus with abnormal retinal correspondence, normal retinal correspondence can be developed by means of the after-image treatment.

\section{Summary}

A series of 22 patients with abnormal retinal correspondence were treated by Cüppers's after-image method, and in four cases normal retinal correspondence was established.

The authors would like to thank Mr. T. Keith Lyle for all the advice and help he has so willingly given in the preparation of this article, and Miss $\mathrm{C}$. Douthwaite for carrying out the follow-up examinations. 
The after-image technique was carried out on the major synoptophore as supplied by Clement Clarke Ltd. It was fitted with a special attachment to produce the after-image, as well as an electronic flashing unit to produce alternating stimulation.

\section{REFERENCES}

BieLsChowsKy, A. (1937). Arch. Ophthal. (Chicago), 17, 408.

BURIAN, H. M. (1947). Ibid., 37, 336. (1951). Ibid., 46, 73 .

Chavasse, F. B. (1939). "Worth's Squint". Baillière, Tindall, and Cox, London.

CüPPERS, C. (1956). Klin. Mbl. Augenheilk., 129, 579.

DUKE-EldER, S. (1949). " "Text-book of Ophthalmology", vol. 4. Kimpton, London.

GraEfe, A. von. Cited by Duke-Elder (1949).

Lyle, T. KeITH, and JACKSON, S. (1940). "Practical Orthoptics in the Treatment of Squint", 2nd ed. Lewis, London. and WALKER, M. (1950).

MüLLER, J. (1826). Cited by Duke-Elder (1949).

Parinaud, H. (1899). Cited by Duke-Elder (1949), p. 3811.

Travers, T. A'B. (1940). Brit. J. Ophthal., $24,58$. (1950). Trans. Amer. Acad. Ophthal. Otolaryng. 54, 561. 